bulmeurt (Hyoscyamus niger). Også illegale stoffer som heroin tilsettes (kuttes) noen ganger med andre stoffer, som skopolamin.

Substanser med antikolinerge egenskaper hemmer binding av acetylkolin til muskarinreseptorer ved kompetitiv inhibering. Stoffene sies derfor å være antimuskarinerge. Muskarinreseptorer finnes i perifert postganglionært nervevev, glatt muskulatur (spesielt i tarm, bronkier og hjertet), sekretoriske kjertler, ciliærlegemet $\mathrm{i}$ øyet og i sentralnervesystemet.

Blokkering av muskarinreseptorer gir derfor et klinisk bilde med kutan vasodilatasjon, anhidrose, mydriasis og et spekter av symptomer fra sentralnervesystemet varierende fra agitasjon, konfusjon og dysartri til psykoser, koma og kramper. Symptomer kommer 3-8 timer etter inntak, og stammer hovedsakelig fra sentralnervesystemet og hjerte- og karsystemet. Først ses russymptomer, oppstemthet, konfusjon og unormal oppførsel, og etter hvert nedsatt bevissthetsgrad. Bevissthetsgraden kan være vekslende. Andre symptomer er blant annet sterk uro, angst, palpitasjoner, magesmerter, hallusinasjoner, oppkast og brystsmerter. Ved undersøkelse finnes ofte takykardi og hypereller hypotensjon. Blodtrykksfallet kan utvikle seg til kardiovaskulær kollaps, og man kan se EKG-forandringer med økt QT-tid og risiko for arytmier av typen torsades de pointes (7), store pupiller, munntørrhet, ruborøs hud spesielt i ansiktet, tørre slimhinner og urinretensjon.

Klassisk klinisk bilde ved antikolinerg forgiftning er derfor dilaterte, ofte lysstive pupiller, takykardi og/eller arytmier, tørre slimhinner, rød/varm hud, urinretensjon og delirium.

Differensialdiagnoser til antikolinergt syndrom innbefatter alle sykdomstilstander og stoffer som kan gi agitert delirium og redusert bevissthet.

Behandling av antikolinergt syndrom med fysostigmin er meget effektivt, men bør forbeholdes pasienter med et fulminant antikolinergt syndrom, dvs. med både sentrale og perifere symptomer (8), som hos den aktuelle pasienten - selv om bivirkninger og komplikasjoner er få (9). Behandlingen krever overvåking av pasienten, da det er risiko for kolinerge bivirkninger, spesielt arytmier og kramper. Kolinerge bivirkninger kan være kardiale (arytmier), sentralnervøse (kramper), gastrointestinale (kvalme/brekninger, diaré), fra luftveier (bronkospasme) i tillegg til urininkontinens, miose, tåreflod og svettereaksjon. Relative kontraindikasjoner er derfor astma/kols, epilepsi, tarmobstruksjon og ledningsforstyrrelser i hjertet. Ved noen sentre behandler man overdoser med trisykliske antidepressiver hvor QRS-kompleksene er over 100 millisekunder, eller det er ventrikulære arytmier i tillegg, med bikarbonatinfusjon til $\mathrm{pH}$ er ca 7,5.

Pasienten har gitt samtykke til at artikkelen blir publisert.

Oppgitte interessekonflikter: Ingen
Litteratur

1. Kanich W, Brady WJ, Huff JS et al. Altered menta status: evaluation and etiology in the ED. Am J Emerg Med 2002; 20: 613-7.

2. Forsberg S, Hojer J, Enander C. Coma and impaired consciousness in the emergency room characteristics of poisoning versus other causes. Emerg Med J 2009; 26: 100 -2

3. Raknes G, Schjøtt JD. Dosering av legemidler ved overvekt og undervekt. Tidsskr Nor Legeforen 2008; 128: 1843-4.

4. Litovitz TL, Klein-Schwartz W, Rodgers GC jr. et al. 2001 Annual report of the American Association of Poison Control Centers Toxic Exposure Surveillance System. Am J Emerg Med 2002: 20: $391-452$

5. Watson WA, Litovitz TL, Rodgers GC jr. et al. 2004 Annual report of the American Association of Poison Control Centers Toxic Exposure Surveillance System. Am J Emerg Med 2005; 23: $589-666$
6. Amlo H, Haugeng KL, Wickstrom E et al. Forgiftning med piggeple. Fem tilfeller behandlet med fysostigmin. Tidsskr Nor Lægeforen 1997; 117: $2610-2$.

7. Hasan RA, Zureikat GY, Nolan BM. Torsade de pointes associated with Astemizole overdose treated with magnesium sulfate. Pediatr Emerg Care 1993; 9: 23-5.

8. Martin B. Howell PR. Physostigmine: going going ... gone? Two cases of central anticholinergic syndrome following anaesthesia and its treatment with physostigmine. Eur J Anaesthesiol 1997; 14: 467-70.

9. Schneir AB, Offerman SR, Ly BT et al. Complications of diagnostic physostigmine administration to emergency department patients. Ann Emerg Med 2003; 42: 14-9.

Manuskriptet ble mottatt 1.4. 2009 og godkjent 5.11. 2009. Medisinsk redaktør Are Brean.

\title{
Kommentar
}

\section{Om å tenke utenfor boksen}

Noen differensialdiagnoser er vanskeligere å huske på enn andre. Det kan være dem med uklare eller uspesifikke symptomer. Årsaken kan være at de er sjeldne eller at vi ikke er oppmerksomme nok. Fire ulike syndromer knyttet til sentralnervesystemet kan synes spesielt vanskelige å erkjenne. Ved siden av antikolinergt syndrom har vi akutt delirium, serotonergt syndrom og malignt nevroleptikasyndrom. Tenker vi ofte nok på disse potensielt dødelige tilstandene?

Felles for dem er at de har mange utløsende agenser og kan ha relativt uspesifikke symptomer som kan være vanskelig å skille fra en forverring av grunnlidelsen. Ofte vil det være en hjelp å kjenne og ha fulgt utviklingen til pasienten over tid for å kunne gjennomføre en god differensialdiagnostikk. Har man det, kan man få hjelp til å oppfatte endringer til det verre som noe uvanlig.

Men artikkelen til Brandsæter og medarbeidere illustrerer at det også kan være motsatt. At det kan være vanskelig å tenke «utenfor boksen» når man treffer en pasient som man synes man kjenner godt. Flere møter med samme pasient eller samme typen pasienter kan gjøre oss blind for at ting ikke er det samme som før. Allmennmedisinere vil kjenne igjen dette. Mange pasienter kommer for å bli beroliget for tilstander som ikke er alvorlige, men så, innimellom kommer den ene som du må tenke annerledes på. Den ene hvor symptomet eller det som sies bør få oss til å tenke oss om.

Artikkelen gir et innblikk i hvordan et antikolinergt syndrom kan se ut. Forfatterne beskriver godt en vanskelig diagnose. Den kan ha ulike ansikter (sentralnervøs agitasjon eller retardasjon og perifere symptomer), utløses av mange ulike agenser (mange ulike legemidler og naturmidler, med og uten ruspotensial) og har mange potensielle differensialdiagnoser (elektrolyttforstyrrelser, organsvikt, hjerneskade, psykisk lidelse og mange andre tilstander). I forhold til disse komplekse og sammensatte bakgrunner og vurderinger er behandlingen relativt enkel. Fysostigmin (Anticholium) 2-3 mg skal settes langsomt (f.eks. $1 \mathrm{mg}$ per minutt). Norsk legemiddelhåndbok for helsepersonell indikerer dosering opp til $4 \mathrm{mg}$ (1), mens andre advarer mot dette pga. faren for perifer kolinerg aktivitet (2). Effekten kan dog reverseres med atropin. Effekten kommer raskt - etter 3-8 minutter, men fordi den varer relativt kort, kan det være nødvendig å gjenta etter noen timer.

Selv om mange av symptomene i denne kasuistikken ikke var forenlig med intoksikasjon ved inntak av benzodiazepiner eller alkohol, så var det riktig å starte med livreddende behandling. I et akuttmottak eller i en sykehusavdeling har man prosedyrer som sikrer at man tar det viktigste først, stabiliserer og sikrer før man går videre.

For også her er det vanligste vanligst. Fra bayesiansk statistikk kan vi imidlertid lære at sannsynligheten for noe uvanlig øker etter hvert som vi har utelukket det vanlige. Deretter skal med andre ord de fire nevnte syndromer rinne oss i hu.

\section{Jørgen G. Bramness}

j.g.bramness@medisin.uio.no

Senter for rus og avhengighetsforskning

Universitetet i Oslo

Kirkeveien 166, Oslo 0407

Oppgitte interessekonflikter: Ingen

\section{Litteratur}

1. Vilberg A. Norsk legemiddelhåndbok for helsepersonell. Oslo: Foreningen for utgivelse av norsk legemiddelhåndbok, 2007.

2. Moos DD. Central anticholinergic syndrome: a case report. J Perianesth Nurs 2007; 22: 309-21. 